ARTICLE

Received 17 Apr 2015 | Accepted 8 Nov 2015 | Published 18 Dec 2015

DOl: $10.1038 /$ ncomms10157

OPEN

\title{
Selenium isotope evidence for progressive oxidation of the Neoproterozoic biosphere
}

Philip A.E. Pogge von Strandmann¹,2, Eva E. Stüeken ${ }^{3}$, Tim Elliott ${ }^{2}$, Simon W. Poulton ${ }^{4}$, Carol M. Dehler ${ }^{5}$, Don E. Canfield ${ }^{6} \&$ David C. Catling ${ }^{2,3}$

Neoproterozoic (1,000-542 Myr ago) Earth experienced profound environmental change, including 'snowball' glaciations, oxygenation and the appearance of animals. However, an integrated understanding of these events remains elusive, partly because proxies that track subtle oceanic or atmospheric redox trends are lacking. Here we utilize selenium (Se) isotopes as a tracer of Earth redox conditions. We find temporal trends towards lower $\delta^{82 / 76}$ Se values in shales before and after all Neoproterozoic glaciations, which we interpret as incomplete reduction of Se oxyanions. Trends suggest that deep-ocean Se oxyanion concentrations increased because of progressive atmospheric and deep-ocean oxidation. Immediately after the Marinoan glaciation, higher $\delta^{82 / 76}$ Se values superpose the general decline. This may indicate less oxic conditions with lower availability of oxyanions or increased bioproductivity along continental margins that captured heavy seawater $\delta^{82 / 76}$ Se into buried organics. Overall, increased ocean oxidation and atmospheric $\mathrm{O}_{2}$ extended over at least 100 million years, setting the stage for early animal evolution.

\footnotetext{
${ }^{1}$ Institute of Earth and Planetary Sciences, University College London and Birkbeck, University of London, Gower Street, London WC1E 6BT, UK. ${ }^{2}$ Bristol Isotope Group, School of Earth Sciences, Bristol University, Wills Memorial Building, Queen's Road, Bristol BS8 1RJ, UK. ${ }^{3}$ Department of Earth and Space Sciences, University of Washington, Seattle, Washington 98195, USA. ${ }^{4}$ School of Earth and Environment, University of Leeds, Leeds LS2 9JT, UK.

${ }^{5}$ Department of Geology, Utah State University, Logan, Utah 84322, USA. ${ }^{6}$ NordCEE, University of Southern Denmark, 5230 Odense M, Denmark.

Correspondence and requests for materials should be addressed to P.A.E.P.v.S. (email: p.strandmann@ucl.ac.uk).
} 
T he history of atmospheric and oceanic redox is strongly interrelated with controls on biological evolution. One of the most significant changes in redox conditions occurred during the late Neoproterozoic $\mathrm{Era}^{1}$, alongside low-latitude 'Snowball Earth' glaciations and the emergence of metazoans ${ }^{2}$. The surface ocean is generally considered to have been oxygenated long before the first Neoproterozoic glaciation, the Sturtian, occurring $\sim 716 \mathrm{Myr}$ ago $^{1,3,4}$. However, deeper waters remained anoxic and ferruginous $\left(\mathrm{Fe}^{2+}\right.$ containing) for much of the Neoproterozoic, with fully oxic conditions becoming widespread (but not global) after the Gaskiers glaciation at $\sim 580 \mathrm{Myr} \mathrm{ago}^{5}$. Extensive deep-ocean oxygenation in the aftermath of the Gaskiers glaciation may have been a consequence of a rise in atmospheric oxygen driven by an influx of nutrients to the ocean during glacial melting ${ }^{6}$. Oxygenation may then have permitted the emergence of animal motility leading to predation and bioturbation, as well as biomineralization ${ }^{1}$. A possible rise in atmospheric oxygen at this time is supported by chromium isotope systematics during the later Neoproterozoic ${ }^{7,8}$, while an increased range in sulphur isotope compositions of biogenic pyrite has been interpreted to reflect increased atmospheric oxygen penetration into nearshore sediments $^{9,10}$. Critically, however, proxies that can temporally resolve the progressive oxidation of the late Neoproterozoic and early Cambrian ocean are lacking, as existing proxies often require specific depositional conditions, or are only applicable to tracking more extreme redox changes such as identifying fully anoxic or oxic conditions.

Selenium (Se) isotopes in marine shales are a novel tracer of ocean and atmospheric oxygenation across the Neoproterozoic Oxygenation Event ${ }^{11-14}$. Selenium has four oxidation states: +6 , $+4,0$ and -2 , and although the biogeochemical Se cycle shares similarities with that of sulphur, there are distinct differences, including redox transitions. Se oxyanion reduction (both $\mathrm{Se}^{\mathrm{VI}}$ and $\mathrm{Se}^{\mathrm{IV}}$ ) occurs at significantly higher Eh than the reduction of sulphate to sulphide ${ }^{15}$, and is closer to that of $\mathrm{Fe}^{3+}$ to $\mathrm{Fe}^{2+}$ (Fig. 1). The combination of multiple redox states, high redox potential and relatively low abundance may also make Se highly sensitive to redox changes ${ }^{16}$. This sensitivity and associated fractionation mechanisms mean that Se isotopes should have responded to the oxygenation of the deep ocean in the Neoproterozoic when the extent of euxinic and ferruginous water masses contracted significantly ${ }^{5}$.

In the modern surface ocean, Se exists as selenite $\left(\mathrm{Se}^{\mathrm{IV}}\right)$ or selenate $\left(\mathrm{Se}^{\mathrm{VI}}\right)$ anions (collectively denoted $\mathrm{SeO}_{x}{ }^{2-}$ ) and dis- solved organic Se (denoted $\mathrm{Se}_{\mathrm{org}}$ ). These species have different behaviour and fates depending on the oxygen levels in the water column. Selenium oxyanions have a short, nutrient-like behaviour and residence time (1,100-9,400 years, although a recent estimate suggests 26,000 years during the Phanerozoic) $)^{15,17,18}$. Organic selenium is common and generally dominates ${ }^{15,19}$ in surface waters, but is reoxidized at depth in oxic water columns (Fig. 2a) and has very low concentrations below the modern photic zone ${ }^{20}$. In modern anoxic water columns, in contrast, the remineralization of organic matter is limited, so that $\mathrm{Se}_{\text {org }}$ dominates below the chemocline ${ }^{16,20}$. The sedimentary archive consists of organic and reduced Se, where the former dominates in sediments deposited in anoxic environments ${ }^{16}$.

About $85 \%$ of the input flux of Se to the oceans (Fig. 2b) arises from rivers, through a combination of organic-bound $\mathrm{Se}^{16}$ and oxidative weathering of continental selenides to $\mathrm{SeO}_{x}^{2-}$; almost all the rest comes from subaerial volcanism via rainfall. Hydrothermal fluid input is small $(<1 \%$ (ref. 16)), and in any case its $\mathrm{Se}$ is probably scavenged by minerals close to the vent ${ }^{21,22}$. It has also been suggested that hydrothermal fluxes were insignificant in the Archaean and earlier Proterozoic ${ }^{13,16}$.

Here we reconstruct redox across the second oxygen rise, using marine shale Se isotope ratios. These are novel tracers of oceanic redox conditions, where lighter isotope ratios in shales are generally indicative of a large pool of oxyanions, implying more oxic conditions. There is an overall trend towards lighter isotope ratios from before the Sturtian glaciation to the Ediacaran-Cambrian boundary. Where time periods are covered by data from more than one sample suite, it suggests that the sediment Se isotopes reflect global redox changes. Therefore, we suggest that the global ocean became more oxic from at least the end of the Marinoan glaciation, and that, rather than a sudden redox change, the shift towards deep-ocean oxia was spread over a timescale of $\sim 100 \mathrm{Myr}$ ago.

\section{Results}

Samples. We report Se isotope ratios and Se concentrations for marine shales from seven different geological sections that together span from 770 to $525 \mathrm{Myr}$ ago. Sample suites include the Mackenzie Mountains, Canada (the Twitya and Sheepbed formations), the Yangtze Platform (comprising samples from the Doushantuo, Luichapo and Niutitang formations), Tapley Hill, Australia and finally from the Mineral Fork Formation, and Uinta Mountain and Chuar groups, western USA.
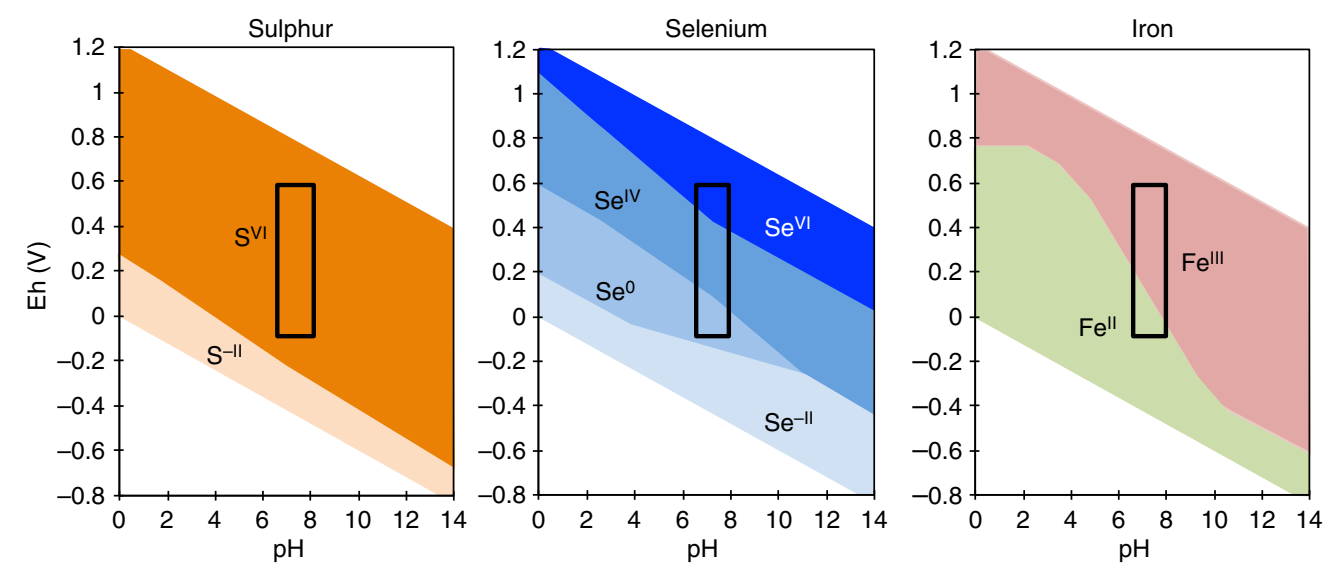

Figure 1 | Redox speciation diagrams. Redox speciation of sulphur, selenium and iron. The black boxes show the range of Eh our Se isotope data suggest oceanic redox must have passed through during the interval $770-525 \mathrm{Myr}$ ago ago ${ }^{65}$. The $\mathrm{pH}$ range also represents the oceanic conditions envisaged for this time interval 66 . 
a

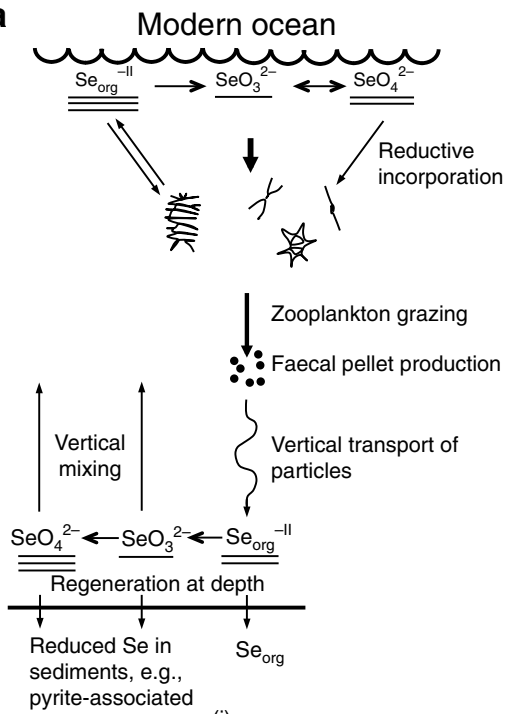

(i)
Proterozoic seawater

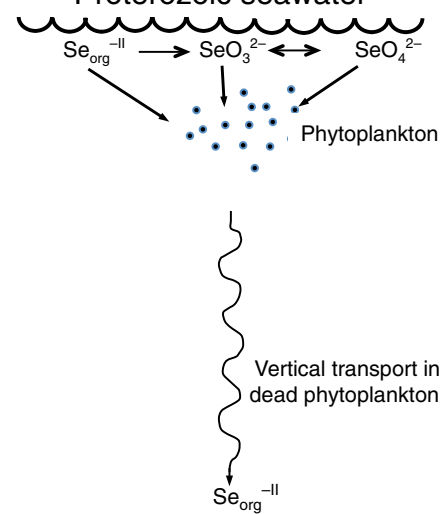

$\mathrm{No} /$ little $\mathrm{SeO}_{\mathrm{x}}^{2-}$ oxidation at depth

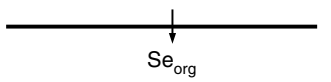

(ii)

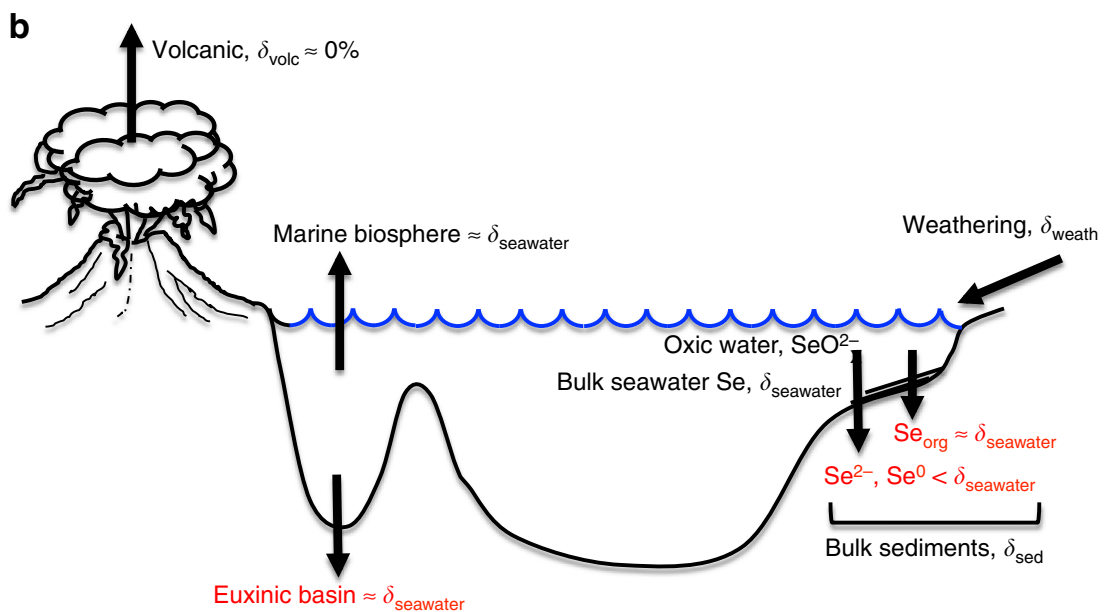

Figure 2 | Summary of selenium and selenium isotope cycling in seawater. (a) (i) Modern cycling of Se in seawater, following Cutter and Bruland 47. Underlines indicate relative concentrations in surface and deep water. Reduction of Se and incorporation into phases in sediments can impart negative isotope fractionation. (ii) Possible cycling of Se in Proterozoic seawater when the deep ocean was not oxygenated and had little $\mathrm{SeO}{ }_{x}^{2-}$. Reduction of Se from oxyanions would have been very limited. (b) A simplified diagram showing the main inputs and outputs in the geological selenium cycle ${ }^{16}$ (analogous to a very similar global scheme developed for isotopes of $\mathrm{Mo}$, which is also a chalcophile element ${ }^{67}$ ). The main inputs to the ocean are volcanic and weathering fluxes with $\delta^{82 / 76} \mathrm{Se}$ values of $\delta_{\text {volc }}$ and $\delta_{\text {weath, }}$ respectively ${ }^{22}$. A key output (highlighted in red) is the largely quantitative removal in isolated euxinic basins, which captures the bulk $\delta^{82 / 76} \mathrm{Se}$ value in seawater, $\delta_{\text {seawater }}$ Another key output, which we sample in our measurements, is removal of Se into sediments on slope or shelf environments in two key components that are mixed in the sediments with Se isotopic composition, $\delta_{\text {sed }}{ }^{11,12,15,22,49}$. The first form is organically bound selenium ( $\mathrm{Se}_{\text {org }}$ ), which likely captures seawater isotopic composition, $\delta_{\text {seawater }}$ The second form is selenide ( $\left(\mathrm{e}^{2-}\right.$ ) or elemental selenium $\left(\mathrm{Se}^{0}\right)$ produced from the microbial reduction of seawater selenite or selenate $\left(\mathrm{SeO}_{x}^{2-}\right)$. Because of isotopic fractionation, this second component tends to sequester lighter selenium isotopes. In the above diagram, we ignore small oceanic Se inputs from deep-sea hydrothermal sources and their outputs in the deep sea, because this Se does not mix into the oceans ${ }^{21}$. Cycling of Se from ocean to atmosphere and back via volatile biogenic organic selenides also does not cause isotope fractionation.

Both formations from Canada are a part of the Windermere Supergroup. The Twitya Formation represents continental slope deposition on a passive margin, where water depths may have reached $\sim 1 \mathrm{~km}$ (ref. 23). In contrast, the Sheepbed Formation was deposited in a deep-water outer shelf setting ${ }^{23}$. Both Formations contain assemblages of spheromorphic acritarchs, as well as Ediacara-type fossils. The Yangtze Platform, China, comprises several formations according to the nomenclature of ref. 5 (Niutitang, Doushantuo and Liuchanpo). They are thought to represent deposition on the lower continental slope to deep basin of a passive margin setting 24,25 . The Tapley Hill Formation is from the Adelaide Rift Complex, Australia. It was deposited in a relatively shallow epicontinental basin of about $200-300 \mathrm{~km}$ width, with apparent access to the global ocean ${ }^{26}$.

Four members of the Chuar Group (Grand Canyon, USA) were analysed, including samples from the Walcott Member $\left(742 \mathrm{Myr} \mathrm{ago}^{27}\right)$, the Awatubi Member ( $745 \mathrm{Myr}$ ago upper, $750 \mathrm{Myr}$ ago lower $\left.^{28}\right)$, the Carbon Canyon Member $(\sim 755 \mathrm{Myr}$ ago) and the Jupiter Member $\left(760 \mathrm{Myr} \mathrm{ago}^{28}\right)$. The group was deposited in an intracratonic extensional basin between $\sim 740$ and $780 \mathrm{Myr} \mathrm{ago}^{29}$. The depositional setting was marine to marginal marine, with access to the open ocean during transgressions, recorded by both sedimentological (wave and tide influenced deposition) and palaeontological evidence ${ }^{30}$. 
Samples from three different Formations of the Uinta Mountain Group (Utah, USA) were also analysed. The group correlates with the Chuar Group, using sedimentological, geochemical, palaeontological and geochronological data ${ }^{31}$. The Uinta Mountain Group was deposited in an intracratonic extensional basin during the early stages of the breakup of Rodinia $^{31}$. The quartzose shale of the Red Pine Shale (sample age $740 \mathrm{Myr}$ ago, based on correlation with the Chuar Group) indicates a prodelta marine environment ${ }^{31}$. The sample from the Moosehorn Lake formation (sample age $765 \mathrm{Myr}$ ago, based on correlation with eastern Uinta Mountain Group formation of Outlaw Trail ${ }^{31}$ ) represents a marine setting, which was connected to the open ocean. Finally, the Deadhorse formation $(\sim 760 \mathrm{Myr}$ ago, stratigraphically above the Moosehorn Lake Formation) represents a barrier bar environment, and as such can be considered to be marine, albeit nearshore ${ }^{31}$.

Finally, a single sample from the Mineral Fork formation was analysed. Zircons in this Formation have been dated at $\sim 700 \mathrm{Myr}$ ago, and other detrital zircon peaks in correlative successions are dated at $700-680 \mathrm{Myr}$ ago ${ }^{32}$. Hence, while using the earlier dates of the Sturtian onset from ref. 4 (based partly on Twitya) of $\sim 717 \mathrm{Myr}$ ago, the maximum depositional age of the Mineral Fork ( $\sim 700 \mathrm{Myr}$ ago $)$ suggests a later glacial effect further south ${ }^{32}$.

Sample chronology is taken from several studies ${ }^{5,31,32}$. In general, these are based on correlation between absolute ages of individual dated layers. The sample dates between the Sturtian and Marinoan have been adjusted to the new timing of the Sturtian ${ }^{4}$, by maintaining the relative timing from ref. 5 , and condensing the absolute ages.

Shale Se isotope record. Selenium concentrations in our sample shales vary widely $\left(0.02-39.5 \mu \mathrm{gg}^{-1}\right)$, with some correlation between [Se] and TOC (total organic carbon; Table 1; Fig. 3). This suggests that some sedimentary Se was buried bound to organic matter, as expected ${ }^{12,33}$. There is also a generally positive, but poor $\left(r^{2}=0.2\right)$ relationship between [Se] and the proportion of highly reactive Fe bound in pyrite, suggesting a weaker effect of substitution for $\mathrm{S}$ in pyrite. However, none of these parameters correlate with Se isotope ratios (Fig. 4), showing that $\delta^{82 / 76} \mathrm{Se}$ are controlled differently from Se concentrations, which again is anticipated for Se behaviour and may reflect changing reservoir effects over time or between basins ${ }^{12,16}$

The measured range of our Neoproterozoic samples $(-2.35$ to $+3.63 \%$, where the Se isotope ratio is reported relative to NIST-3149 (refs 34-36); Fig. 5; Table 1) is generally similar to the full range of unaltered Phanerozoic and Archaean shale $11-14,16,22,37-39$, which might be expected if the data reflect a transitional interval from relatively low to higher oxygen levels. Indeed, the data show an overall decrease in $\delta^{82 / 76} \mathrm{Se}$ with time, from the highest values in pre-Sturtian sediments, through to the lowest values at the Precambrian-Cambrian boundary ( $\sim 550 \mathrm{Myr}$ ago). In detail, the data become isotopically lighter in the run-up to each of the three glaciations, but after the Marinoan glaciation, $\delta^{82 / 76} \mathrm{Se}$ is reset at higher values. This return to higher $\delta^{82 / 76} \mathrm{Se}$ is not apparent after the Gaskiers glaciation, but an excursion to moderately heavier values occurs during an euxinic interval in the early Cambrian Yangtze Basin. Where samples from two different basins overlap in age (that is, pre-Sturtian, immediately post-Sturtian and between the Marinoan and Gaskiers at 625-584 Myr ago, Fig. 5), we find a remarkable consistency of $\delta^{82 / 76}$ Se values, which may suggest that our data represent global processes rather than local redox changes or diagenetic alteration. It has been proposed that $\mathrm{Se}$ isotopes can become highly fractionated during modern oxidative weathering of exposed, very Se-rich ( $\leq 26 \mathrm{wt} \%)$, outcrops ${ }^{38}$, where it appears that Se was oxidized and then re-reduced during aqueous transport. However, other studies of Se poorer soils have reported much less fractionation $(<0.5 \%)^{40}$, and the studies of large global data sets also suggest that isotopic effects of late-stage weathering of outcrops are probably not significant ${ }^{12,16}$. The highly fractionated values from the Se-rich soil ${ }^{38}$ may thus not be representative of all exposed surface environments. In any case, we present Se data from a combination of cores and outcrops $5,31,32$, and from different global localities, the combination of which should guard against significant latestage diagenetic and weathering effects. In addition, for outcrop material, all weathered edges were cut away, and these samples often contain significant pyrite and $\mathrm{Fe}$ carbonate minerals suggesting minimal oxidation ${ }^{5}$, as confirmed by conventional and cathodoluminescence petrographic techniques ${ }^{41}$. Iron speciation data suggest that most of this study's samples were ferruginous, albeit with some euxinic conditions at the Precambrian-Cambrian boundary (Table 1$)^{5,42}$.

\section{Discussion}

The Se isotopic composition of volcanically derived Se is likely to be similar to that of the mantle $\left(\delta^{82 / 76} \mathrm{Se} \sim 0-0.25 \%\right.$ (refs 16,43$)$ ). During oxidative weathering, relatively small fractionations of $\sim 0-0.4 \%$ occur ${ }^{40}$. However, during dissimilatory or abiotic oxyanion reduction in some modern and ancient lakes and rivers, isotopically light Se is sequestered in sediments, driving surface waters heavy by over 3\%o (refs 16,44). Overall, modern ocean inputs are probably close to $\sim 0 \%$ on average, but may have differed in the past. Significant positive values in marine sediments from most of the earlier Precambrian may indicate that fluvial Se was isotopically heavy due to partial reduction during transport ${ }^{16}$. Marine plankton are thought to assimilate $\mathrm{Se}$ without fractionation and the isotopic composition of $+0.42 \pm 0.22 \%$ in modern phytoplankton ${ }^{12}$ suggests that pre-industrial seawater $\mathrm{SeO}_{x}^{2-}$ may have had $\delta^{82 / 76} \mathrm{Se} \sim+0.4 \%$ (refs 12,16,22). This elevated isotope ratio compared with the likely input must be balanced by accumulation of selenium with lower $\delta^{82 / 76} \mathrm{Se}$ in average marine sediments ${ }^{12}$.

Selenium can be preserved in sediments in three different forms. On a global scale, most modern selenium is biologically reduced by assimilation and deposited as $\mathrm{Se}_{\text {org, }}$ with little inherent isotope fractionation $(<0.9 \%)^{15,16,44,45}$. Another component of sedimentary $\mathrm{Se}$ may be $\mathrm{Se}^{\mathrm{IV}}$ adsorbed onto Fe-oxyhydroxides. This process also imparts a relatively small isotope fractionation of on average $\sim 0.15 \%$ (refs 45,46 ). The third component comprises inorganic reduced phases $\left(\mathrm{Se}^{0}\right.$ and $\mathrm{Se}^{-\mathrm{II}}$ in sulphide minerals) that form via microbial dissimilatory reduction under suboxic conditions. Given that a significant fraction of the sedimentary $\mathrm{Se}$ is associated with organic matter $^{47,48}$, any potential inorganic $\mathrm{Se}^{-\mathrm{II}}$ or $\mathrm{Se}^{0}$ phases that formed by oxyanion reduction and may carry more negative $\delta^{82 / 76} \mathrm{Se}$ values become diluted ${ }^{16}$. This may explain why natural bulk sediments generally show much smaller fractionations relative to Se sources to the ocean than what is observed in laboratory experiments ${ }^{16}$.

Isotopic fractionation of selenium species in sediments is related to the redox state of the overlying water. Both experimental $^{11}$ and $a b$ initio calculations ${ }^{49}$ have reported fractionation of $\Delta^{82 / 76} \mathrm{Se}_{\text {oxyanions-SeO }} \leq-21 \%$, although natural fractionation is considerably smaller ${ }^{12,16}$. In any case, $a b$ initio equilibrium calculations likely do not reflect the largely kinetic fractionation likely occurring in natural systems ${ }^{47,50}$. The additional reduction of $\mathrm{Se}^{0}$ to selenide is not associated with significant isotope fractionation ${ }^{11}$. Thus, where dissimilatory 
Table 1 | Se concentration and isotope data for the analysed samples.

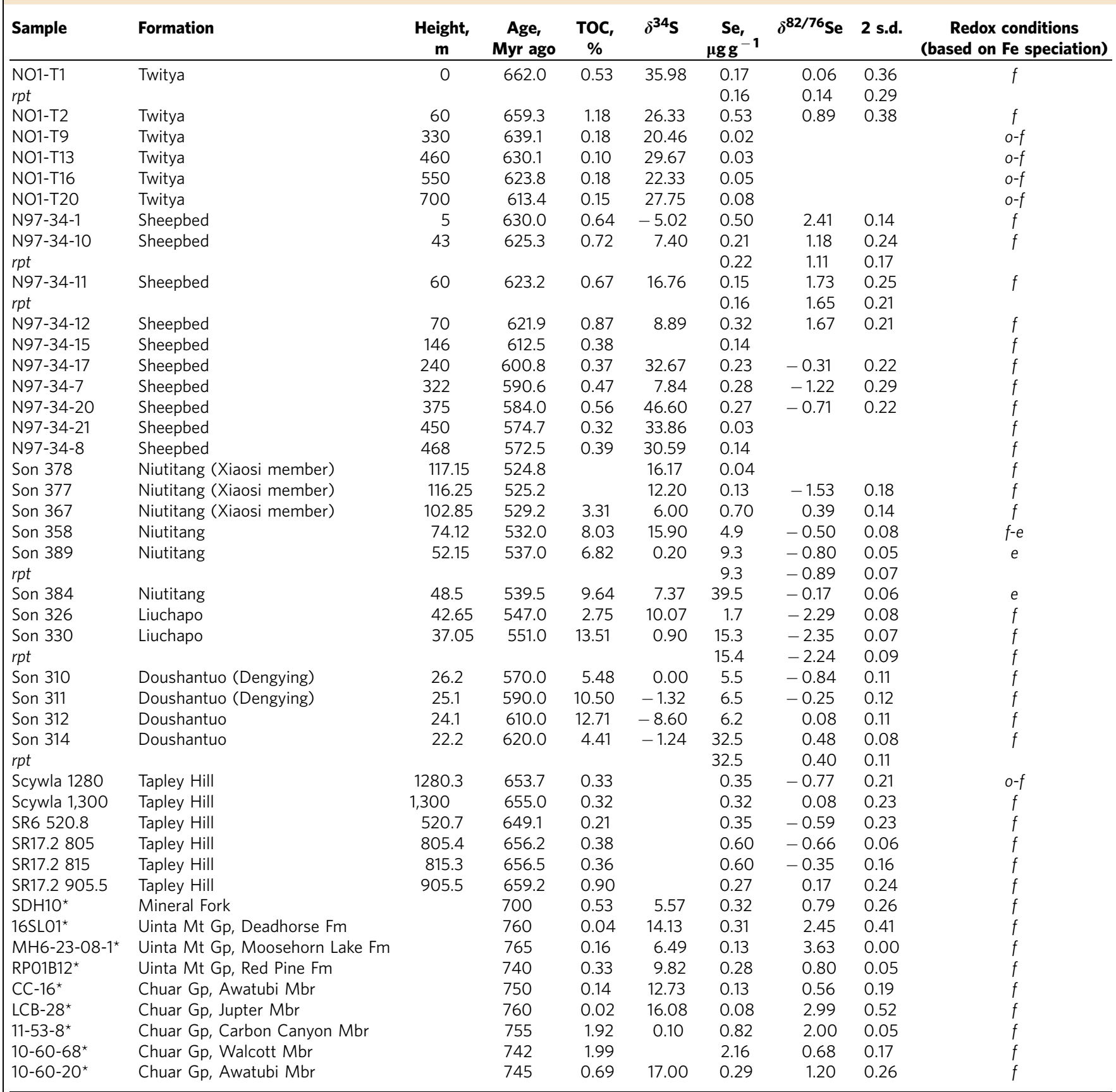

e, euxinic; $f$, ferruginous; f-e, ferruginous-euxinic boundary; o-f, oxic-ferruginous boundary 60 ; TOC, total organic carbon.

Additional information from refs 5,31. All Se isotope data analysed by the double-spike method of Pogge von Strandmann et al. ${ }^{35}$, except those marked by ${ }^{\star}$, where the method is that of Stüeken et al. ${ }^{36}$. Additional information from refs 5,31. All Se isotope data analysed by the double-spike meth
The final column details the depositional redox conditions, based on Fe speciation $5,30,42$.

reduction of $\mathrm{SeO}_{x}^{2-}$ occurs, it sequesters lighter isotopes into sediments. If the site of the reduction (for example, suboxic sediments or oxygen-minimum zones (OMZs) in the water column) is linked to a large Se oxyanion reservoir, as, for example, the modern oxic ocean, then $\mathrm{SeO}_{x}^{2-}$ reduction may be non-quantitative, such that sedimentary reduced phases preserve large negative fractionations ${ }^{14,15,39}$. Therefore, one would expect that an increase in the size of the dissolved $\mathrm{SeO}_{x}{ }^{2-}$ reservoir correlates with larger and more negative fractionations in locally suboxic environments. Selenium isotope compilations from across geological time statistically support this relationship, with mean isotope ratios heaviest in the mid-Archaean before the onset of oxidative weathering around $\sim 2.7 \mathrm{Gyr}$ ago $\left(\delta^{82 / 76} \mathrm{Se}=+0.93 \pm 0.41 \%\right.$, 1 s.d.; Fig. $\left.6 \mathrm{a}\right)$, intermediate in the early to middle Proterozoic ( $+0.68 \pm 0.83 \%$, up to $\sim 1.1 \mathrm{Gyr}$ ago), and lightest in the Phanerozoic $(-0.30 \pm 0.89 \%)^{16}$. Shorter-term trends in sedimentary Se isotope ratios confirming the same patterns have been reported from the latest Archaean ${ }^{13}$, the Permo-Triassic (P-Tr) boundary ${ }^{39}$, Mesozoic Oceanic Anoxic Events (OAEs; although these appear to exhibit basinal gradations ${ }^{12,16}$ ) and glacial-interglacial redox variations in the Cariaco Basin $^{22}$. 


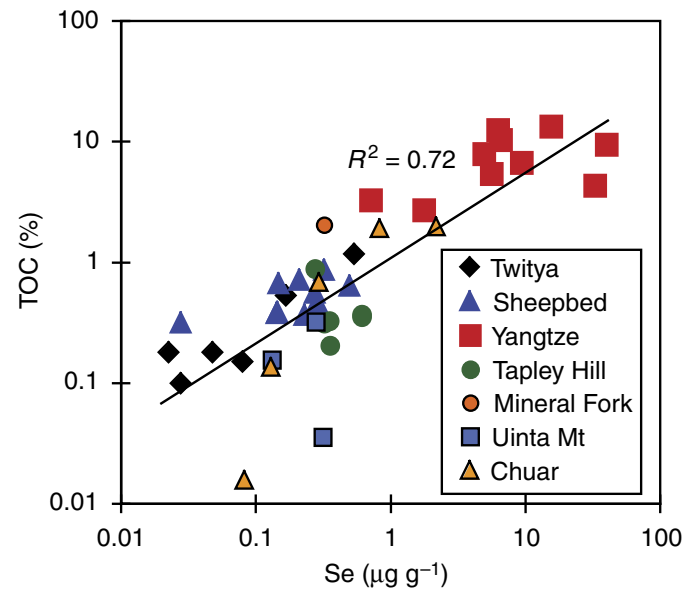

Figure 3 | Correlation between total organic carbon and Se concentrations. The co-variation with TOC (total organic carbon), for all samples from all of this study's different sample locations, suggests that $\mathrm{Se}_{\text {org }}$ is an important Se phase in sediments.

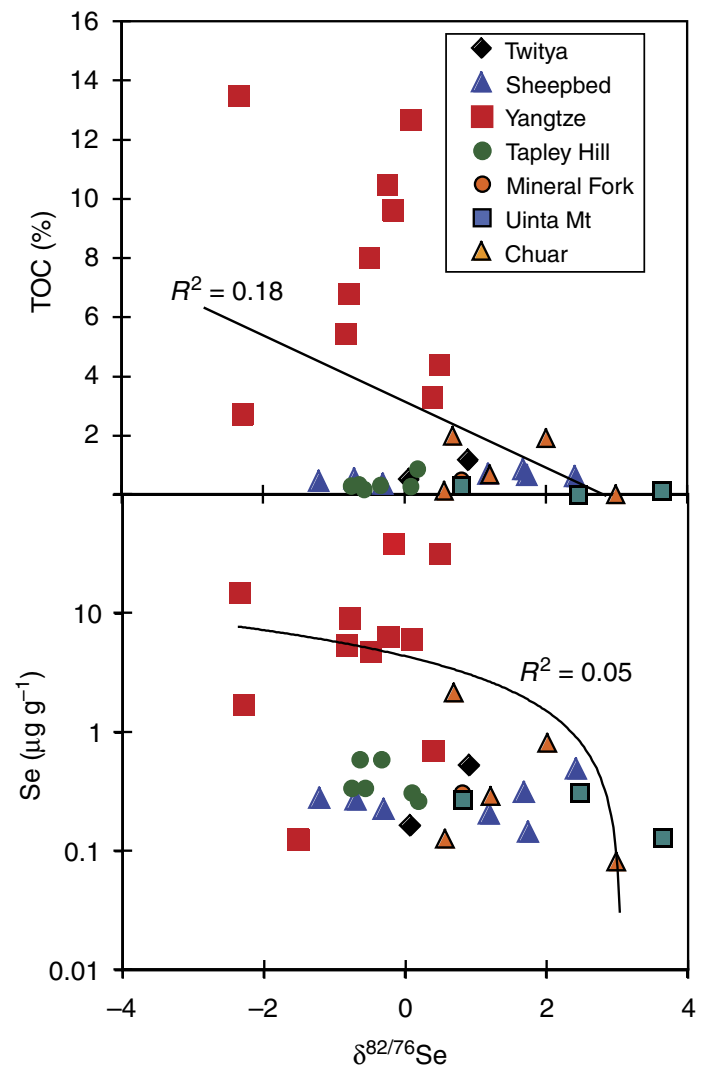

Figure 4 | The lack of a linear relationship between Se isotopes and TOC and Se concentrations. The lack of correlations between any of the parameters, as demonstrated by the $R^{2}$ values and trend lines, shows different controls on $\mathrm{Se}$ isotopes from those that control Se concentrations.

The interpretation of a link between redox trends and Se isotopic composition may be complicated by temporal variations in the compositions of inputs to the oceans (dominantly riverine fluxes), and by local redox changes in restricted basins or marginal seas that are not representative of the global ocean. The former implies that seawater $\delta^{82 / 76} \mathrm{Se}$ has changed at key intervals in Earth history, as also suggested for Mo isotopes ${ }^{51,52}$. The latter is particularly important for Se due to its short marine residence

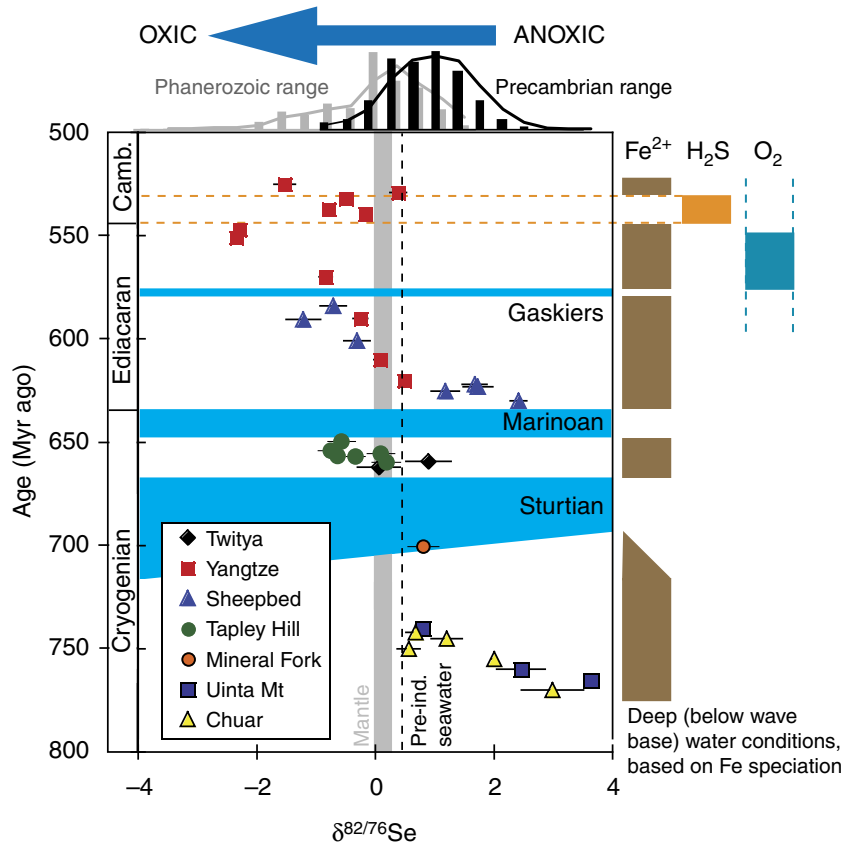

Figure 5 | Se isotope data for Late Neoproterozoic marine sediments. The vertical grey bar represents the mantle $\delta^{82 / 76} \mathrm{Se}^{43}$, and the vertical dashed line represents likely pre-industrial modern seawater $\delta^{82 / 76} \mathrm{Se} \mathrm{S}^{12,22}$. Blue horizontal bars represent glacial intervals. The black histogram shows the range of Precambrian $\delta^{82 / 76} \mathrm{Se}^{13}$, while the grey histogram shows the range of Phanerozoic shale data ${ }^{12,14}$. Deep-water redox conditions are also shown on the right, based on Fe speciation data for the same sediments. Ferruginous deep-water conditions dominate around the Sturtian and Marinoan glaciations. Post-Gaskiers redox conditions are more variable globally, with evidence for widespread ocean oxygenation, but a continuation of ferruginous conditions in some basins. The diachronous initiation of the Sturtian glaciation is based on the geological evidence (see Sample section).

time and its high sensitivity to changes in biological productivity ${ }^{39}$. Locally enhanced productivity may increase the relative proportion of $\mathrm{Se}_{\mathrm{org}}$, which would lead to a smaller net fractionation of bulk sediments relative to seawater, because the dissolved $\mathrm{SeO}_{x}^{2-}$ reservoir becomes locally depleted and because $\mathrm{Se}_{\text {org }}$ dilutes any fractionation carried by inorganic reduced phases. Hence, global, rather than local, redox conditions can only be inferred with confidence if similar trends and values occur in multiple different settings of similar age. Therefore, as with all tracers of marine redox conditions (for example, Mo isotopes ${ }^{53}$ ), Se isotopes provide information on local water column and water-sediment interface conditions, with an additional control from global seawater isotope ratios.

Published modern ( $<500 \mathrm{kyr}$ old $)$ data clearly show that sediments deposited in the oxic open ocean, or under well-connected OMZs, have isotopically lighter Se than those deposited in anoxic, restricted basin conditions ${ }^{16,22}$. The lighter values probably reflect the large $\mathrm{SeO}_{x}^{2-}$ reservoir in oxic seawater, which allows for incomplete dissimilatory reduction under locally suboxic conditions, such as during early diagenesis in sediments or in OMZs. In contrast, sediments deposited under anoxic or euxinic conditions incur little to no isotopic fractionation, likely due to a combination of more quantitative $\mathrm{SeO}_{x}^{2-}$ reduction, a higher proportion of $\mathrm{Se}_{\text {org }}$, and a local increase in the isotopic composition of dissolved $\mathrm{SeO}_{x}^{2-}$ due to Rayleigh distillation ${ }^{6}$. In ferruginous systems, preferential removal of isotopically light Se by abiotic reduction with $\mathrm{Fe}(\mathrm{II})$ 


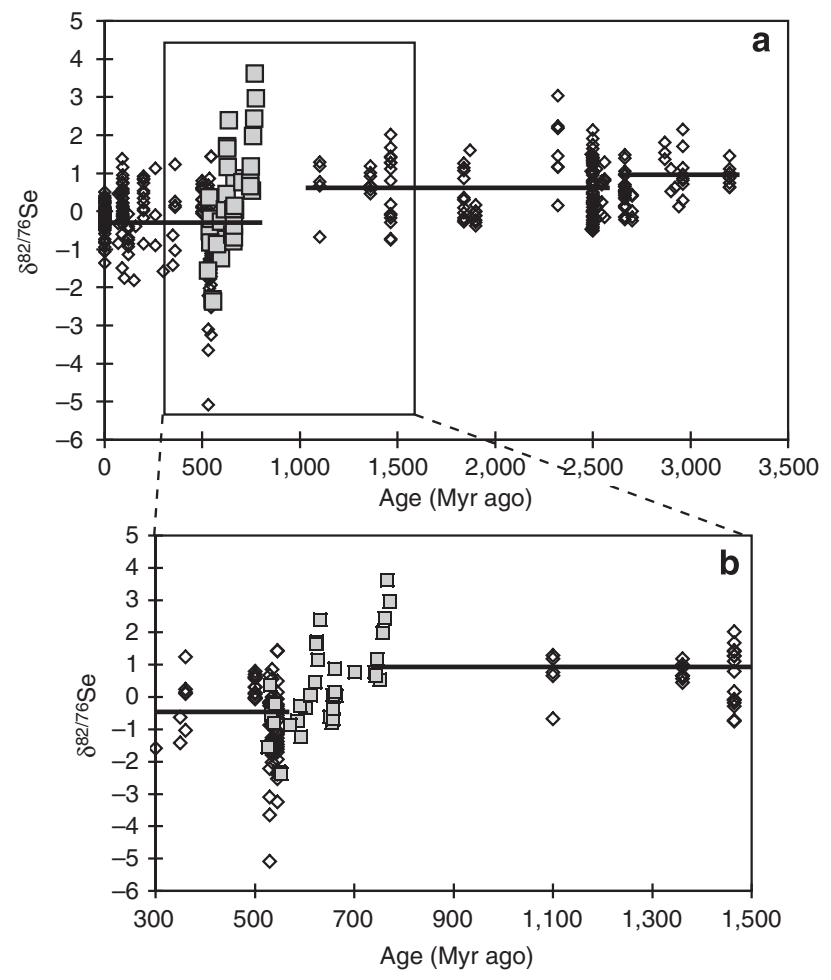

Figure 6 | Compilation of all published global sedimentary Se isotope data from marine settings. (a) Published data (open symbols) ${ }^{16}$ compared with data from this study (closed squares) $(n=463)$. The horizontal lines represent the mean from each time period ${ }^{16}$, demonstrating the overall trend towards isotopically lighter sediments after each major oceanic oxidation stage. (b) A focus of the same data compilation to the time period of this study. Here the black lines show the data mean from 1,500 Myr ago to the Sturtian $(+0.92 \pm 0.76 \%$ ), and from the Gaskiers to the present $(-0.32 \pm 0.85 \%)$.

may play a role, with experimental results suggesting large fractionations, although it is unknown whether these experiments reflect the degree of fractionation in a natural state $11,14,16,46,54$. It has been suggested that light Se isotope ratios reported from the early Cambrian Yangtze platform may be due to this process ${ }^{14}$, but in this case the ferruginous reduction site was likely linked to a large Se oxyanion reservoir such as the global ocean or a deep oxic surface layer ${ }^{16,46}$. Overall, over geologic time, marine sediments have become isotopically lighter, in response to the overall oxidation of the ocean-atmosphere system (Fig. 6) ${ }^{16}$. The trend towards more negative values in our Neoproterozoic $\delta^{82 /}$ ${ }^{76} \mathrm{Se}$ data (Fig. 5) is thus most plausibly interpreted as deep-water oxygenation and an increase in the marine $\mathrm{SeO}_{x}{ }^{2-}$ reservoir towards the Precambrian-Cambrian boundary. Excursions from other time periods (latest Archaean ${ }^{13}, \mathrm{P}-\mathrm{Tr}$ boundary ${ }^{39}$, $\mathrm{OAEs}^{12,16}$ and glacial-interglacial redox variations ${ }^{22}$ ) have been interpreted in a similar manner, lending support to our Neoproterozoic interpretation.

One key observation is that $\delta^{82 / 76}$ Se values before the Sturtian and immediately after the Marinoan are isotopically heavier than both the mantle and average Precambrian values (Fig. 5). The highest Precambrian $\delta^{82 / 76} \mathrm{Se}$ value published before this study is $+3.04 \%$ from $\sim 2.3 \mathrm{Gyr}$ ago ${ }^{16}$, compared with our highest values of $+3.63 \%$ at $0.765 \mathrm{Gyr}$ ago, and positive values are generally observed in the Archaean ${ }^{16}$. Highly positive values are also reported from the first 'whiff of oxygen'13 and during a local euxinic event shortly before the Permo-Triassic mass extinction ${ }^{39}$.
Several possibilities can be proposed for driving sediment $\delta^{82 / 76}$ Se higher than crust or mantle values in the Precambrian. The first is that Precambrian rivers became isotopically heavy. Early rivers could have contained a large fraction of organically complexed Se, due to land-based microbial life. In this case, increasing atmospheric oxygen could have increased the $\mathrm{SeO}_{x}{ }^{2-} / \mathrm{Se}_{\text {org }}$ ratio, generating more reduction of $\mathrm{SeO}_{x}{ }^{2-}$ in rivers, driving the residue to higher $\delta^{82 / 76} \mathrm{Se}$ values ${ }^{16}$. This scenario is reasonable given that late Archaean lake and river sediments are isotopically lighter than marine sediments from the same time, indicating heavier continental surface waters ${ }^{16}$, assuming a similar fractionation mechanism in fresh and seawater. This phenomenon has also been reported from modern lakes with changing redox ${ }^{44}$. As during the late Archaean 'whiff of oxygen'3 3 , the pre-Sturtian $\delta^{82 / 76}$ Se peak in our data set may thus reflect an atmospheric rise in $\mathrm{pO}_{2}$ above background levels without significant seawater oxygenation. A second possibility is that a Se isotope gradient with ocean depth could have formed, where continuous removal of light Se into sediments in shallower oxic waters would enrich offshore waters in heavy isotopes, also driving sediments downslope to isotopically heavier compositions. Such behaviour has been proposed to explain Archaean Se data ${ }^{13}$, as well as suggested for molybdenum isotopes ${ }^{13,53}$. However, it is only likely to apply here if the intracratonic basin represented by the Uinta Mountain and Chuar data had a universally deep chemocline everywhere in the basin. Hence, the isotopically heavy data might indicate that rivers became isotopically heavier at these times, likely due to relatively sudden increases in atmospheric $\mathrm{O}_{2}$ during the run-up to oceanic oxygenation. In fact, the most positive values around $770 \mathrm{Myr}$ ago approximately coincide with a large perturbation in $\mathrm{Cr}$ isotopes, which has been interpreted as evidence of atmospheric oxygenation before the Sturtian glaciation ${ }^{7}$. Given that during the Marinoan $\mathrm{CO}_{2}$ levels appear to have increased ${ }^{55-57}$, and therefore $\mathrm{O}_{2}$ levels decreased, there could have been another $\mathrm{O}_{2}$ rise soon after the Marinoan, which may again have led to isotopically heavy Se in river waters. The increasing availability of oxygen is also consistent with high proportions of organic carbon burial in interglacial times ${ }^{58}$. Exceptionally high $\delta^{82 / 76} \mathrm{Se}$ is not observed after the Sturtian, but this may be because our samples are slightly older relative to deglaciation, compared with the post-Marinoan samples. A third possibility for high $\delta^{82 / 76} \mathrm{Se}$ values is high organic carbon burial. Enhanced biological productivity along continental margins could also have directly contributed to the observed heavy $\delta^{82 / 76} \mathrm{Se}$ after the Marinoan glaciations, because such conditions may have locally enhanced the proportion of $\mathrm{Se}_{\text {org }}$ in sediments.

Changing riverine Se isotope ratios are unlikely to have caused the trend towards isotopically light values observed in our samples, because there is no plausible mechanism that would drive river waters isotopically light. The few riverine sediments from the geologic past that have been measured have significantly lighter $\delta^{82 / 76} \mathrm{Se}$ than the crustal value ${ }^{16}$, implying isotopically heavy waters. Hence the negative fractionations in marine sediments are likely the result of in situ $\mathrm{SeO}_{x}{ }^{2-}$ reduction, either within sedimentary pore waters or in suboxic bottom waters. Importantly, the preservation of light $\delta^{82 / 76}$ Se values relative to the crust implies that reduction was not quantitative. One possible explanation is a massive drop in productivity, such as observed during the $\mathrm{P}-\mathrm{Tr}$ extinction $^{39}$, which would lead to a decline in $\mathrm{Se}_{\text {org }}$ deposition. Although carbon burial may indeed have declined after its initial post-glacial boost $t^{58}$, there is no overall correlation between Se and $\mathrm{C}$ isotopes (Fig. 7). Therefore, the trend towards lighter values is probably a reflection of an increasing $\mathrm{SeO}_{x}{ }^{2-}$ reservoir in the Neoproterozoic ocean, that is, an increase in Se supply rather than 


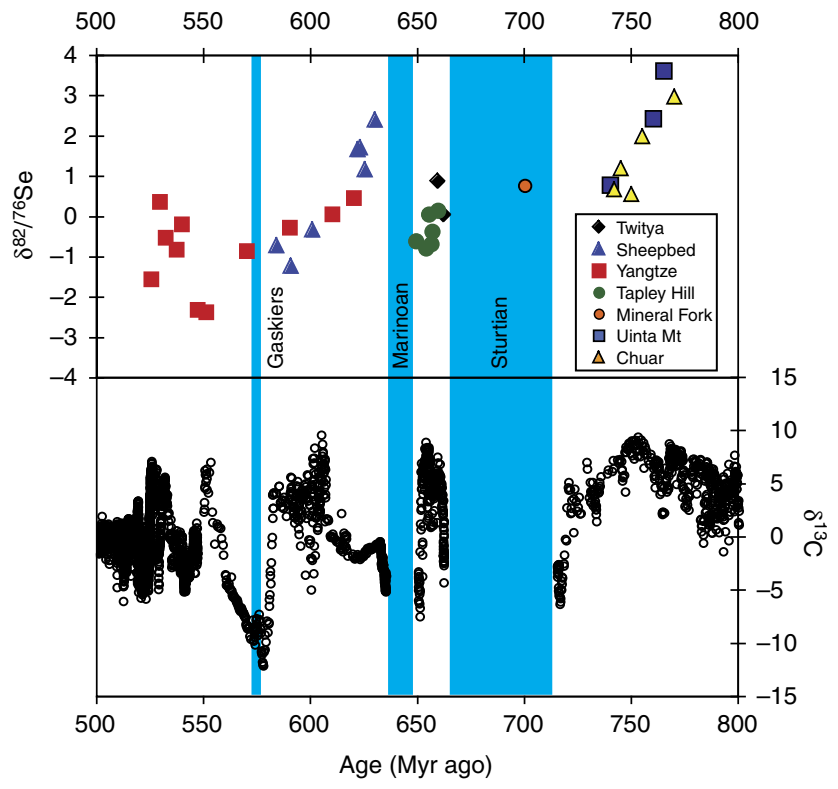

Figure 7 | Comparison of this study's Se isotope data with composite C isotope data. Se isotopes suggest that the oxidation of the oceans took at least $100 \mathrm{Myr}$ ago. The lack of correlation with $\delta^{13} \mathrm{C}$ suggests that the processes that control carbon (burial and oxidation of organic matter and carbonate dissolution/formation) ${ }^{68}$ appear not to be controlling Se isotopes, meaning that $\mathrm{Se}$ is not controlled by organic matter. The timing of the Sturtian has been altered according to ref. 4 (Sturtian is not shown as diachronous, as opposed to Fig. 5, for simplicity's sake).

a decrease in demand. The fact that multiple basins of similar age show similar patterns suggests that dissolved $\mathrm{SeO}_{x}^{2-}$ concentrations increased globally, which is consistent with widespread oxygenation of the deep ocean.

A key complication in interpreting sedimentary Se isotopes (or indeed any redox proxy) is the influence of local redox changes in the water column, relative to global oceanic oxidation changes. Localized changes in redox (for example, 'euxinic wedges') are thought to have occurred towards the end of the Cryogenian, especially at intermediate depths $s^{5,59,60}$. Such local changes would be assumed to complement or override Se isotope variations caused by global ocean changes, as, for example, also shown for redox tracers such as $\mathrm{Mo}$ and $\mathrm{Cr}$ isotopes ${ }^{7,8,53}$. In addition, the closer-to-quantitative capture of Se in more reduced settings would likely decrease the Se residence time before oxygenation ${ }^{12,16}$, enhancing local effects. The clearest method for attempting to determine a local versus global Se isotope signal is to compare sample suites from different global locations. Thus, similar $\delta^{82 / 76} \mathrm{Se}$ values between the data from Chuar and Uinta Mountain groups between $\sim 770$ and $742 \mathrm{Myr}$ ago suggest that, at least in the intracratonic basin associated with these groups, Se isotope ratios rapidly decreased. Immediately after the Sturtian (662-659 Myr ago), our Twitya and Tapley Hill samples give similar $\delta^{82 / 76} \mathrm{Se}$ values, and at times between the Marinoan and Gaskiers $(\sim 625-584)$, similar isotope ratios are seen from the Sheepbed and Yangtze sample suites. Given that these suites are from different continents and different ocean depths, this suggests that Se isotope ratios between the Sturtian and Gaskiers generally represent global ocean phenomena (except, potentially, high $\delta^{82 / 76} \mathrm{Se}$ in the Sheepbed samples immediately after the Marinoan). Combined, these samples nevertheless suggest that global ocean sediments were becoming isotopically lighter during the course of the end-Cryogenian and Ediacaran.
Data after the Gaskiers glaciation only exist from the Yangtze Platform, and, therefore, there is nothing to prove that trends recorded here are more than local redox changes. However, the large $\delta^{82 / 76}$ Se variation recorded from the Yangtze (from $-2.3 \%$ to $+0.4 \%$, followed by a return to negative values) provide a natural experiment that supports our interpretation of a redox control on $\delta^{82 / 76} \mathrm{Se}$. At $\sim 540 \mathrm{Myr}$ ago, Fe speciation suggests a localized, transient, $\sim 10 \mathrm{Myr}$ interval of euxinia ${ }^{5}$. Once euxinia starts, $\delta^{82 / 76}$ Se values increase substantially, and approach $\sim 0 \%$, reflecting near-quantitative removal of Se from seawater under euxinic conditions, in the form of sulphides and $\mathrm{Se}_{\mathrm{org}}$ (refs 12,13,61). Sections from elsewhere in the Yangtze Basin display similarly high $\delta^{82 / 76} \mathrm{Se}$ values ${ }^{14}$ (Fig. 5). Then, once Fe speciation indicates a cessation of euxinia, $\delta^{82 / 76} \mathrm{Se}$ decreases again. Thus, sediments deposited under more reducing conditions have significantly higher $\delta^{82 / 76} \mathrm{Se}$ values than those deposited under more oxic conditions, as also implied by rapid $^{12,13,39}$ and long-term ${ }^{16}$ oceanic trends.

Selenium's redox transitions result in Se isotopes being sensitive to redox conditions between those of $\mathrm{S}^{-\mathrm{II}}-\mathrm{S}^{\mathrm{IV}}$ and $\mathrm{Fe}^{\mathrm{II}}-\mathrm{Fe}^{\mathrm{III}}$. Hence, our data imply that at $\sim 770 \mathrm{Myr}$ ago, coastal to intermediate depth (the depositional environment of the Chuar and Uinta Mt. groups) Eh was below the $\mathrm{Se}^{\mathrm{IV}}-\mathrm{Se}^{0}$ transition, with reducing conditions widespread on shallow shelves, coupled to likely changes in the riverine isotope ratio, in response to atmospheric oxygenation. Afterwards, temporal trends in $\delta^{82 / 76} \mathrm{Se}$ imply that the oceans became progressively oxidized, as evidenced by deep marine depositional environments from different global locations showing increasingly lower $\delta^{82 / 76} \mathrm{Se}$ values. Global seawater reached a minimum around the Gaskiers glaciation (as shown by low values in both the Sheepbed and Yangtze), and potentially a lower minimum at the Precambrian-Cambrian boundary, although local effects cannot be distinguished here, because only one location was sampled from this time period. It is interesting to note that other samples of roughly similar age (also from the Yangtze Platform ${ }^{14}$ ) show even lighter Se isotope ratios (Fig. 6).

Overall, the Neoproterozoic data from this study fit well into the trends of Se isotope data over geologic time ${ }^{16}$ (Fig. 6). Samples before the Sturtian and after the Marinoan glaciations are isotopically heavier than the next youngest samples from $\sim 400$ to $700 \mathrm{Myr}$ ago earlier ${ }^{16}$. As discussed above, heavy values before the Sturtian could be a function of local conditions during intracratonic basinal deposition, where riverine influence on shallow waters would be relatively greater, and may not reflect wider global conditions. Heavy values after the Marinoan are also only reflected by one sample suite, but could also reflect changing continental weathering conditions during recovery from the 'snowball' glaciation.

Hence, our data appear to capture an important transitional interval from high $\delta^{82 / 76} \mathrm{Se}$ values typical of the Archaean and early Proterozoic ${ }^{12,13,16}$ to the lighter values that characterise the Phanerozoic ${ }^{12,14,16,22,35,38,39}$ (Figs 5 and 6). This shift is consistent with oxygenation of the deep ocean during this time period, and in particular, suggests that the shift between fully ferruginous and fully oxic deep oceans took considerable time. The possibility that the trend towards lower $\delta^{82 / 76} \mathrm{Se}$ was caused by a relaxation in organic burial (and hence less heavy $\mathrm{Se}_{\text {org }}$ burial) is unlikely because there is no correlation between $\delta^{82 / 76} \mathrm{Se}$ and $\delta^{13} \mathrm{C}$ (Fig. 7).

The selenium isotope data imply that oxygenation was a protracted process. Iron speciation indicates that fully oxic deep waters only formed after the Gaskiers glaciation ${ }^{5}$. The Se isotope data suggest that this oxidation was spread over time, likely starting after the Marinoan, and taking around $100 \mathrm{Myr}$ to pass through ferruginous and intermediate redox conditions 
(for example, manganous) to reach full deep-ocean oxia. Selenium's low abundance, multiple redox states and high redox potential may make Se isotopes a more sensitive redox proxy than tracers such as sulphur or molybdenum isotopes ${ }^{16}$, or 'on-off tracers such as Fe speciation. Hence, these data provide insight into the small degrees of redox change that led, perhaps in fits and starts, to full oceanic oxygenation. A CryogenianEdiacaran increase in oxygenation agrees with other redoxsensitive elements ${ }^{10,62,63}$ and biomarker evidence ${ }^{64}$. Thus, the significance of the Se isotope record is not only that it adds to growing evidence that the late Proterozoic and Cambrian ocean and atmosphere reached a progressively more oxic state, coinciding with the diversification of animal life, but also that the process of oxidation was protracted, and not ultimately triggered by the Gaskiers deglaciation, as other data suggest ${ }^{5}$.

In summary, this study has determined Se isotope ratios from shales deposited across the Neoproterozoic Oxygenation Event, from 770 to $525 \mathrm{Myr}$ ago. Selenium isotopes are sensitive to changing oceanic redox conditions, both global and local, where lighter isotope ratios in sediments imply deposition from a water body that was linked to a large, oxic $\mathrm{SeO}_{x}{ }^{2-}$ reservoir. This hypothesis is supported by studies of other geologic time periods, as well as by local redox variations recorded by our post-Gaskiers samples. Overall, we find a trend of decreasing sediment $\delta^{82 / 76} \mathrm{Se}$ with time, and where time periods are covered by data from more than one sample suite, it suggests that the sediment Se isotopes reflect global redox changes. Hence, the data suggest that the global ocean became more oxic from at least the end of the Marinoan glaciation, and that, rather than a sudden redox change, the shift towards deep-ocean oxia was spread over a timescale of $\sim 100$ Myr.

\section{Methods}

Analytical methods. The analytical methods used here for Se isotopes have been reported elsewhere ${ }^{35,36}$, but, briefly, two separate methods were used, where both report relative to NIST SRM-3149 (ref. 34). Samples younger than the Sturtian glaciation ( $\sim 670 \mathrm{Myr}$ ago) were analysed by a double-spike inversion method, where international rock standard results were double-checked using different spikes and inversions, as well as doping and inverse modelling experiments ${ }^{35}$. The chemistry and analyses were performed at the Bristol Isotope Group, UK, using a Thermo Neptune MC-ICP-MS. Data from before the Sturtian were obtained using a sample-standard bracketing technique, with analyses performed on a $\mathrm{Nu}$ Instruments MC-ICP-MS at the University of Washington, USA ${ }^{36}$. To compare the techniques, the USGS shale standard SGR-1 was analysed by both methods The former method yields $\delta^{82 / 76} \mathrm{Se}=+0.25 \pm 0.17 \%$ o $(n=16)$, and the latter $+0.05 \pm 0.18 \%$ o $(n=9)$, meaning that values are identical within analytical uncertainty 35,36 .

\section{References}

1. Shields-Zhou, G. \& Och, L. The case for a Neoproterozoic Oxygenation Event: Geochemical evidence and biological consequences. Geol. Soc. Am. Today 21, 4-11 (2011).

2. Narbonne, G. M. The ediacarabiota: Neoproterozoic origin of animals and their ecosystems. Annu. Rev. Earth Planet. Sci. 33, 421-442 (2005).

3. Macdonald, F. A. et al. Calibrating the Cryogenian. Science 327, 1241-1243 (2010).

4. Rooney, A. D. et al. Re-Os geochronology and coupled Os-Sr isotope constraints on the Sturtian snowball Earth. Proc. Natl Acad. Sci. USA 111, 51-56 (2014).

5. Canfield, D. E. et al. Ferruginous conditions dominated later neoproterozoic deep-water chemistry. Science 321, 949-952 (2008).

6. Canfield, D. E., Poulton, S. W. \& Narbonne, G. M. Late-Neoproterozoic deep-ocean oxygenation and the rise of animal life. Science 315, 92-95 (2007).

7. Planavksy, N. J. et al. Low mid-Proterozoic atmospheric oxygen levels and the delayed rise of animals. Science 346, 635-638 (2014).

8. Frei, R., Gaucher, C., Poulton, S. W. \& Canfield, D. E. Fluctuations in Precambrian atmospheric oxygenation recorded by chromium isotopes. Nature 461, 250-253 (2009).

9. Canfield, D. E. The Early History of Atmospheric Oxygen. Annu. Rev. Earth Planet. Sci. 33, 1-36 (2005).
10. Turner, E. C. \& Bekker, A. Thick sulfate evaporite accumulations marking a mid-Neoproterozoic oxygenation event (Ten Stone Formation, Northwest Territories, Canada). Geol. Soc. Am. Bull. B31268.1 (2015).

11. Johnson, T. M. \& Bullen, T. D. in Geochimistry of Non-Traditional Stable Isotopes. (eds Johnson, C. M., Beard, B. L. \& Albarede, F.) 289-317 (Geochemical Society, 2004).

12. Mitchell, K. et al. Selenium as paleo-oceanographic proxy: a first assessment. Geochim. Cosmochim. Acta 89, 302-317 (2012).

13. Stüeken, E. E., Buick, R. \& Anbar, A. D. Selenium isotopes support free $\mathrm{O} 2$ in the latest Archean. Geology 43, 259-262 (2015).

14. Wen, H. J. et al. Selenium isotopes trace anoxic and ferruginous seawater conditions in the Early Cambrian. Chem. Geol. 390, 164-172 (2014).

15. Fernandez-Martinez, A. \& Charlet, L. Selenium environmental cycling and bioavailability: a structural chemist point of view. Rev. Environ. Sci. Biotechnol. 8, 81-110 (2009).

16. Stüeken, E. E. et al. The evolution of the global selenium cycle: secular trends in Se isotopes and abundances. Geochim. Cosmochim. Acta 162, 109-125 (2015).

17. Mackenzie, F. T., Lantzy, R. J. \& Paterson, V. Global trace metal cycles and predictions. Math. Geol. 11, 99-142 (1979).

18. Large, R. R. et al. Cycles of nutrient trace elements in the Phanerozoic ocean. Gondwana Res. 28, 1282-1293 (2015).

19. Cutter, G. A. \& Cutter, L. S. Sources and cycling of selenium in the western and equatorial Atlantic Ocean. Deep Sea Res. II 48, 2917-2931 (2001).

20. Cutter, G. A. Selenium in reducing waters. Science 217, 829-831 (1982).

21. Layton-Matthews, D. et al. Multiple sources of selenium in ancient seafloor hydrothermal systems: Compositional and $\mathrm{Se}, \mathrm{S}$, and $\mathrm{Pb}$ isotopic evidence from volcanic-hosted and volcanic-sediment-hosted massive sulfide deposits of the Finlayson Lake District, Yukon, Canada. Geochim. Cosmochim. Acta 117, 313-331 (2013).

22. Shore, A. J. T. Selenium geochemistry and isotopic composition of sediments from the Cariaco Basin and the Bermuda Rise: a comparison between a restricted basin and the open ocean over the last $500 \mathrm{ka}$. (PhD thesis Univ. Leicester, 2010).

23. Narbonne, G. M. \& Aitken, J. D. Neoproterozoic of the mackenzie mountains, Northwestern Canada. Precambrian Res. 73, 101-121 (1995).

24. Goldberg, T., Poulton, S. W. \& Strauss, H. Sulphur and oxygen isotope signatures of late Neoproterozoic to early Cambrian sulphate, Yangtze Platform, China: Diagenetic constraints and seawater evolution. Precambrian Res. 137, 223-241 (2005)

25. Goldberg, T., Strauss, H., Guo, Q. \& Liu, C. Reconstructing marine redox conditions for the early Cambrian Yangtze Platform: evidence from biogenic sulphur and organic carbon isotopes. Palaeogeogr. Palaeoclimatol. Palaeoecol. 254, 175-193 (2007).

26. Coats, R. P., Forbes, B. G. \& Preiss, W. V. The Adelaide Geosyncline. Late Proterozoic Stratigraphy, Sedimentation, Palaeontology and Tectonics (Ministry of Mines and Energy, 1987).

27. Karlstrom, K. E. et al. Chuar Group of the Grand Canyon: record of breakup of Rodinia, associated change in the global carbon cycle, and ecosystem expansion by 740Ma. Geology 28, 619-622 (2000)

28. Williams, M. et al. Dating sedimentary sequences: in situ $\mathrm{U} / \mathrm{Th}-\mathrm{Pb}$ microprobe dating of early diagenetic monazite and Ar-Ar dating of marcasite nodules: case study from Neoproterozoic black shales in the southwestern U.S. Geol. Soc. Am. Abst. Program. 35, 595 (2003).

29. Dehler, C. M., Karlstrom, K. E., Gehrels, G. E., Timmons, J. M. \& Crossey, L. C. Stratigraphic revision, provenance, and new age constraints of the Nankoweap Formation and Chuar Group, Grand Canyon Supergroup, Grand Canyon, Arizona. Geol. Soc. Am. Abst. Program. 44, 82 (2012).

30. Dehler, C. M. et al. Neoproterozoic Chuar Group ( 800-742Ma), Grand Canyon: A record of cyclic marine deposition during global climatic and tectonic transitions Vol. 141-142 (Sedimentary Geology, 2001).

31. Dehler, C. M., Fanning, C. M., Link, P. K., Kingsbury, E. M. \& Rybczynski, D. Maximum depositional age and provenance of the Uinta Mountain Group and Big Cottonwood Formation, northern Utah: paleogeography of rifting western Laurentia. Geol. Soc. Am. Bull. 122, 1686-1699 (2010).

32. Yonkee, W. A. et al. Tectono-stratigraphic framework of Neoproterozoic to Cambrian strata, west-central U.S.: protracted rifting, glaciation, and evolution of the North American Cordilleran margin. Earth Sci. Rev. 136, 59-95 (2014)

33. Gustafsson, J. P. \& Johnsson, L. The Association between Selenium and Humic Substances in Forested Ecosystems - Laboratory Evidence. Appl. Organometal. Chem. 8, 141-147 (1994).

34. Carignan, J. \& Wen, H. J. Scaling NIST SRM 3149 for Se isotope analysis and isotopic variations of natural samples. Chem. Geol. 242, 347-350 (2007).

35. Pogge von Strandmann, P. A. E., Coath, C. D., Catling, D. C., Poulton, S. W. \& Elliott, T. Analysis of mass dependent and mass independent selenium isotope variability in black shales. J. Anal. Atom. Spectrom. 29, 1648-1659 (2014).

36. Stüeken, E. E., Foriel, J., Nelson, B. K., Buick, R. \& Catling, D. C. Selenium isotope analysis of organic-rich shales: advances in sample preparation and isobaric interference correction. J. Anal. Atom. Spectrom. 28, 1734-1749 (2013). 
37. Wen, H. J. \& Carignan, J. Selenium isotopes trace the source and redox processes in the black shale-hosted Se-rich deposits in China. Geochim. Cosmochim. Acta 75, 1411-1427 (2011).

38. Zhu, J. M., Johnson, T. M., Clark, S. K., Zhu, X. K. \& Wang, X. L. Selenium redox cycling during weathering of Se-rich shales: A selenium isotope study. Geochim. Cosmochim. Acta 126, 228-249 (2014).

39. Stüeken, E. E., Foriel, J., Buick, R. \& Schoepfer, S. D. Selenium isotope ratios, redox changes and biological productivity across the end-Permian mass extinction. Chem. Geol. 410, 28-39 (2015).

40. Schilling, K., Johnson, T. M. \& Wilcke, W. Selenium Partitioning and Stable Isotope Ratios in Urban Topsoils. Soil Sci. Soc. Am. J. 75, 1354-1364 (2011).

41. Dehler, C. M. et al. High-resolution $\delta 13 \mathrm{C}$ stratigraphy of the Chuar Group (ca. $770-742 \mathrm{Ma})$, Grand Canyon: Implications for mid-Neoproterozoic climate change. Geol. Soc. Am. Bull. 117, 32-45 (2005).

42. Johnston, D. T. et al. An emerging picture of Neoproterozoic ocean chemistry: insight from the Chuar Group, Grand Canyon, USA. Earth Planet. Sci. Lett. 290, 64-73 (2010).

43. Rouxel, O., Fouquet, Y. \& Ludden, J. N. Subsurface processes at the Lucky Strike hydrothermal field, mid-Atlantic Ridge: evidence from sulfur, selenium, and iron isotopes. Geochim. Cosmochim. Acta 68, 2295-2311 (2004).

44. Clark, S. K. \& Johnson, T. M. Selenium stable isotope investigation into selenium biogeochemical cycling in a lacustrine environment: Sweitzer Lake, Colorado. J. Environ. Qual. 39, 2200-2210 (2010).

45. Johnson, T. M., Herbel, M. J., Bullen, T. D. \& Zawislanski, P. T. Selenium isotope ratios as indicators of selenium sources and oxyanion reduction. Geochim. Cosmochim. Acta 63, 2775-2783 (1999).

46. Mitchell, K., Couture, R.-M., Johnson, T. M., Mason, P. R. D. \& Van Cappellen, P. Selenium sorption and isotope fractionation: iron(III) oxides versus iron(II) sulfides. Chem. Geol. 342, 21-28 (2013).

47. Cutter, G. A. \& Bruland, K. W. The marine biogeochemistry of selenium: a reevaluation. Limnol. Oceanogr. 29, 1179-1192 (1984).

48. Baines, S. B., Fisher, N. S., Doblin, M. A. \& Cutter, G. A. Uptake of dissolved organic selenides by marine phytoplankton. Limnol. Oceanogr. 46, 1936-1944 (2001).

49. Li, X. F. \& Liu, Y. Equilibrium Se isotope fractionation parameters: a firstprinciples study. Earth Planet. Sci. Lett. 304, 113-120 (2011).

50. Kulp, T. R. \& Pratt, L. M. Speciation and weathering of selenium in Upper Cretaceous chalk and shale from South Dakota and Wyoming, USA. Geochim. Cosmochim. Acta 68, 3687-3701 (2004).

51. Archer, C. \& Vance, D. The isotopic signature of the global riverine molybdenum flux and anoxia in the ancient oceans. Nat. Geosci. 1, 597-600 (2008).

52. Pearce, C. R., Burton, K. W., Pogge von Strandmann, P. A. E., James, R. H. \& Gislason, S. R. Molybdenum isotope behaviour accompanying continental weathering and riverine transport in a basaltic terrain. Earth Planet. Sci. Lett. 295, 104-114 (2010).

53. Poulson, R. L., Siebert, C., McManus, J. \& Berelson, W. M. Authigenic molybdenum isotope signatures in marine sediments. Geology 34, 617-620 (2006).

54. Charlet, L. et al. Electron transfer at the mineral/water interface: selenium reduction by ferrous iron sorbed on clay. Geochim. Cosmochim. Acta 71, 5731-5749 (2007)

55. Hoffman, P. F., Kaufman, A. J., Halverson, G. P. \& Schrag, D. P. A Neoproterozoic snowball Earth. Science 281, 1342-1346 (1998).

56. Kasemann, S. A., Hawkesworth, C., Prave, A. R., Fallick, A. E. \& Pearson, P. N. Boron and calcium isotope composition in Neoproterozoic carbonate rocks from Namibia: evidence for extreme environmental change. Earth Planet. Sci. Lett. 231, 73-86 (2005).

57. Kasemann, S. A. et al. Calcium and magnesium isotopes elucidate changes in continental weathering following a Cryogenian glaciation. Earth Planet. Sci. Lett. 396, 66-77 (2014).
58. Och, L. M. \& Shields-Zhou, G. A. The Neoproterozoic oxygenation event: Environmental perturbations and biogeochemical cycling. Earth Sci. Rev. 110, 26-57 (2012).

59. Lenton, T. M., Boyle, R. A., Poulton, S. W., Shields-Zhou, G. A. \& Butterfield, N. J. Co-evolution of eukaryotes and ocean oxygenation in the Neoproterozoic era Nat. Geosci 7, 257-265 doi:10.1038/ngeo2108 (2014).

60. Poulton, S. W. \& Canfield, D. E. Ferruginous conditions: a dominant feature of the ocean through Earth's history. Elements 7, 107-112 (2011).

61. Pettine, M., Gennari, F., Campanella, L., Casentini, B. \& Marani, D. The reduction of selenium(IV) by hydrogen sulfide in aqueous solutions. Geochim. Cosmochim. Acta 83, 37-47 (2012).

62. Sahoo, S. K. et al. Ocean oxygenation in the wake of the Marinoan glaciation. Nature 489, 546-549 (2012).

63. Gallagher, M., Turner, E. C. \& Kamber, B. S. In situ trace metal analysis of Neoarchaean - Ordovician shallow-marine microbial-carbonate-hosted pyrites Geobiology 13, 316-339 (2015).

64. Love, G. D. et al. Fossil steroids record the appearance of Demospongiae during the Cryogenian period. Nature 457, 718-722 (2009).

65. Takeno, N. Atlas of Eh-pH diagrams-Intercomparison of thermodynamic databases (2005).

66. Ohnemueller, F., Prave, A. R., Fallick, A. E. \& Kasemann, S. A. Ocean acidification in the aftermath of the Marinoan glaciation. Geology 42, 1103-1106 (2014).

67. Anbar, A. D. \& Rouxel, O. Metal stable isotopes in paleoceanography. Annu. Rev. Earth Planet. Sci. 35, 717-746 (2007).

68. Halverson, G. P., Hoffman, P. F., Schrag, D. P., Maloof, A. C. \& Rice, A. H. N Toward a Neoproterozoic composite carbon-isotope record. Bull. Geol. Soc. Am. 117, 1181-1207 (2005).

\section{Acknowledgements}

We thank Chris Coath for assistance during method development. Graham Shields is thanked for discussions on C isotopes. This study was funded by NERC grant NE/F016832/1. P.A.E.P.v.S. is supported by NERC fellowship NE/I020571/2.

\section{Author contributions}

P.A.E.P.v.S. carried out most of the analyses, interpreted the data and wrote the manuscript, with contributions from all co-authors. E.E.S. supplied some of the Se isotope data, S.W.P., C.M.D. and D.E.C. provided samples and geochemical context. D.C.C. and T.E. wrote the original NERC research proposal, and T.E. helped in method development.

\section{Additional information}

Competing financial interests: The authors declare no competing financial interests.

Reprints and permission information is available online at http://npg.nature.com/ reprintsandpermissions/

How to cite this article: Pogge von Strandmann, P. A. E. et al. Selenium isotope evidence for progressive oxidation of the Neoproterozoic biosphere. Nat. Commun. 6:10157 doi: 10.1038/ncomms10157 (2015).

This work is licensed under a Creative Commons Attribution 4.0 International License. The images or other third party material in this article are included in the article's Creative Commons license, unless indicated otherwise in the credit line; if the material is not included under the Creative Commons license, users will need to obtain permission from the license holder to reproduce the material. To view a copy of this license, visit http://creativecommons.org/licenses/by/4.0/ 